\title{
Rola kompleksu MutS oraz białka MSH2 w kontroli crossing-over u roślin
}

\begin{abstract}
STRESZCZENIE:
$\mathrm{Z}$ jawisko crossing-over polega na wzajemnej wymianie fragmentów chromatyd pomiędzy chromosomami homologicznymi i zachodzi podczas pierwszego podziału mejotycznego. Na ostateczną lokalizację i częstość crossing-over na chromosomie wpływa wiele czynników, m.in. aktywność modyfikatorów działających in trans, stopień metylacji chromatyny czy obecność polimorfizmów pomiędzy rekombinującymi chromosomami. System MMR, a przede wszystkim białko MSH2, służą do rozpoznawania i naprawy nieprawidłowo sparowanych zasad DNA, a w mejozie zapobiegają rekombinacji pomiędzy niedopasowanymi regionami chromosomowymi. Okazuje się, iż u roślin białko MSH2 może pełnić także rolę pro-rekombinacyjną, rozpoznając polimorfizmy i nakierowując zdarzenia crossing-over $\mathbf{w}$ regiony silniej polimorficzne. W niniejszej pracy pokazujemy, jak obecność polimorfizmów może wpływać na chromosomową dystrybucję crossing-over, a w konsekwencji - na ewolucję genomów roślinnych. Jest to szczególnie istotne $w$ przypadku roślin samopylnych, $u$ których naturalnie występuje duży stopień homozygotyczności. Gdyby rekombinacja zachodziła wyłącznie w regionach homozygotycznych, nie dochodziłoby do powstawania nowych genotypów w kolejnych pokoleniach, a ewolucja organizmów byłaby spowolniona.
\end{abstract}

\section{WPROWADZENIE}

Mejoza to proces podziału komórki, niezbędny do wytworzenia haploidalnych gamet, a w konsekwencji umożliwiający rozmnażanie płciowe. Mejoza składa się z dwóch etapów - mejozy I oraz II, których ostatecznym produktem jest komórka płciowa (u zwierząt) lub spora (u roślin i grzybów), zawierająca o połowę mniej materiału genetycznego niż komórka rodzicielska. Podczas profazy I podziału mejotycznego, w fazie zwanej pachytenem, dochodzi do crossing-over, czyli wzajemnej wymiany fragmentów DNA pomiędzy chromosomami homologicznymi. Crossing-over umożliwia wytworzenie nowych kombinacji alleli w potomstwie poprzez przetasowanie materiału genetycznego pochodzącego od obu rodziców. Zjawisko to zapewnia zatem zwiększenie zmienności genetycznej w kolejnych pokoleniach organizmów rozmnażających się płciowo. Crossing-over jest również niezbędne dla prawidłowego rozchodzenia się chromosomów do biegunów komórki w trakcie pierwszego podziału mejotycznego. Zaburzenia w segregacji chromosomów mogą prowadzić do aneuploidii, a więc występowania w komórce nietypowej liczby chromosomów (nadmiaru lub niedoboru). U zwierząt występowanie aneuploidii ma często skutki letalne lub jest powodem występowania poważnych zaburzeń rozwojowych, włączając $w$ to zespół Downa [1,2].

\section{REKOMBINACJA MEJOTYCZNA}

Rekombinacja mejotyczna (crossing-over) inicjowana jest przez wytworzenie podwójnego pęknięcia nici DNA (ang. DNA double-strand break, DSB). Liczba DSB w komórce znacznie przewyższa liczbę zdarzeń crossing-over, które ostatecznie mogą z nich powstać [3]. Na przykład w roślinie modelowej Arabidopsis thaliana w jednej komórce mejotycznej powstaje 200-250 DSB, z których zaledwie 10 jest naprawianych na drodze zdarzeń crossing-over [4]. Pozostałe DSB naprawiane są w oparciu o inne szlaki rekombinacyjne określane jako noncrossover, w których dochodzi co najwyżej do niewzajemnej wymiany krótkiego fragmentu DNA. W przypadku spadku częstości DSB liczba crossing-over pozostaje niezmieniona kosztem mniejszej liczby noncrossover; zjawisko to określane jest jako homeostaza crossing-over [5]. Bez względu na wielkość genomu, ilość crossing-over rzadko przewyższa 3 na parę chromosomów homologicznych [2]. Natomiast konieczne jest wystąpienie co najmniej jednego, tzw. obligatoryjnego crossing-over na parę chromosomów. Zarówno homeostaza crossing-over jak i obligatoryjne crossing-over należą do mechanizmów odpowiedzialnych za ścisłą kontrolę częstości rekombinacji w komórce [6].

\section{mgr Julia Dłużewska ${ }^{\square}$}

\section{prof. UAM dr hab. Piotr A. Ziółkowski ${ }^{\square}$}

Pracownia Biologii Genomu, Instytut Biologii Molekularnej i Biotechnologii, Wydział Biologii, Uniwersytet im. Adama Mickiewicza w Poznaniu, ul. Uniwersytetu Poznańskiego 6, 61-614 Poznań

https://doi.org/10.18388/pb.2021_386

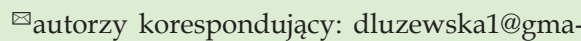
il.com (J.D.), pzio@amu.edu.pl (P.Z.)

Słowa kluczowe: mejoza, crossing-over, Arabidopsis, MSH2, polimorfizmy

Wykaz skrótów: dHJ - podwójna struktura Holliday'a (ang. double Holliday Junction); DSB podwójne pęknięcie nici DNA (ang. - DNA double-strand break); HET - region heterozygotyczny; HOM - region homozygotyczny; MMR - system naprawy nieprawidłowo sparowanych zasad DNA (ang. DNA mismatch repair system)

Podziękowania: Praca powstała w ramach realizacji grantów NCN: Sonata Bis nr 2016/22/E/NZ2/00455 dla PAZ oraz Preludium nr 2020/37/N/NZ2/01226 dla JD; oraz FNP POIR.04.04.00-00-5C0F/17-00 dla PAZ. 


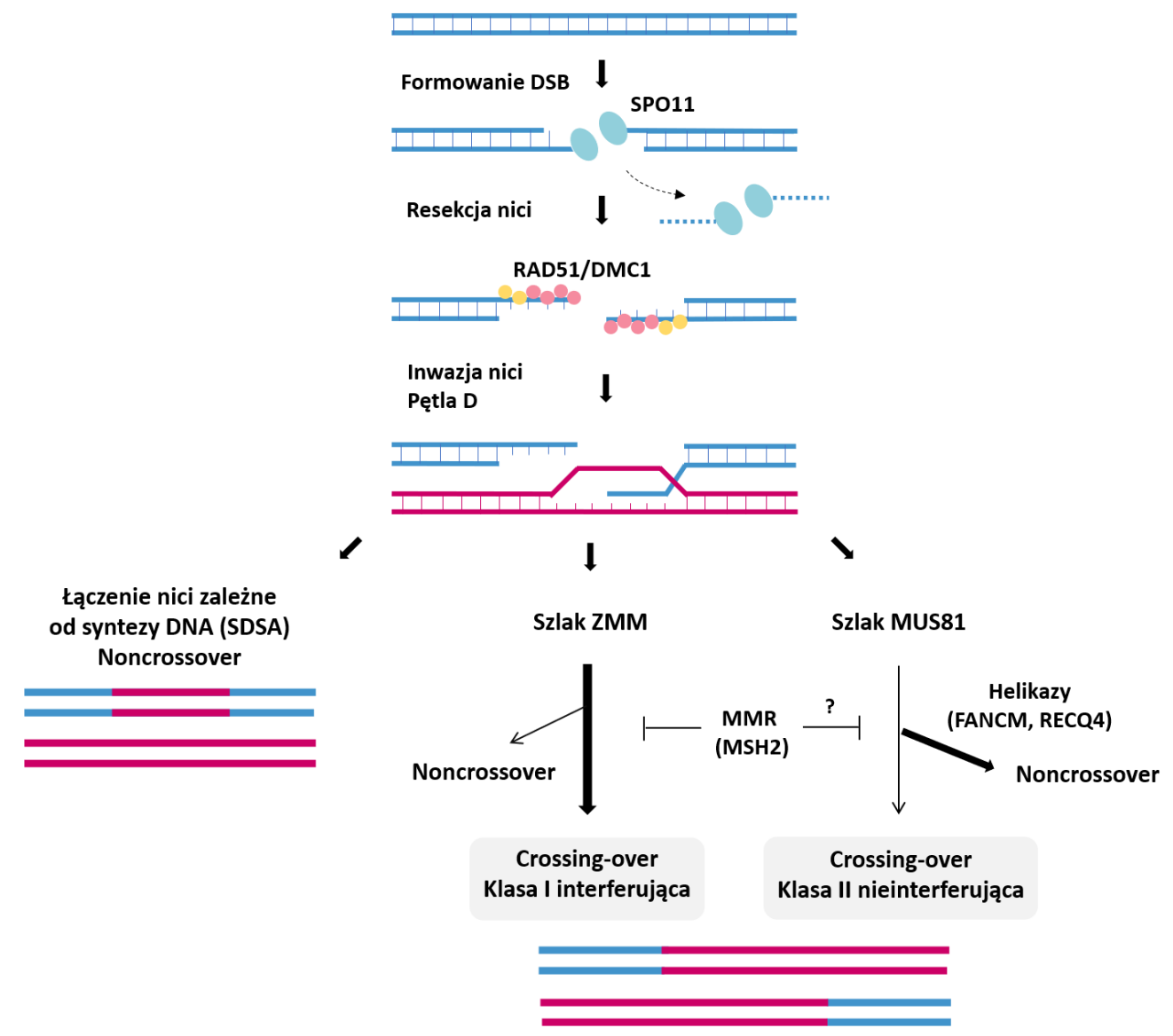

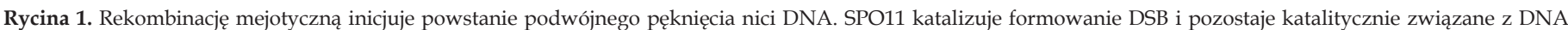

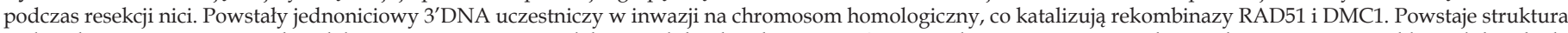

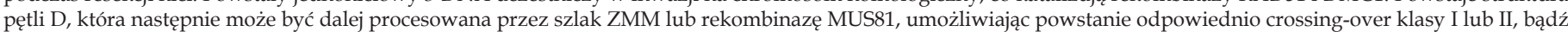
naprawiona jako noncrossover, np. w procesie SDSA. System MMR rozpoznaje nieprawidłowo sparowane nukleotydy i tym samym wpływa na sposób naprawy DSB.

Za powstawanie mejotycznych DSB odpowiada wysoce konserwatywne białko SPO11 (Ryc. 1), działające jako dimer [7]. Resekcja nici powoduje powstanie wolnego końca 3'-OH ssDNA, który związany zostaje przez rekombinazy RAD51 i DMC1. Tworzą one wspólnie nukleofilament atakujący cząsteczkę DNA homologicznego chromosomu. W ten sposób dochodzi do utworzenia pętli D (ang. D-loop), która następnie może zostać przekształcona $\mathrm{w}$ podwójną strukturę Holliday'a (ang. double Holliday Junction, dHJ), a w konsekwencji w zdarzenia crossing-over. Większość powstających crossing-over należy do tzw. klasy I, która jest wrażliwa na zjawisko interferencji (Tabela 1) [8]. Interferencja crossing-over oznacza, że zajście crossing-over $\mathrm{w}$ określonym miejscu chromosomu wpływa ograniczająco na możliwość zajścia kolejnego zdarzenia w jego pobliżu $[9,10]$. Powstawanie crossing-over klasy I kontrolowane jest przez białka szlaku ZMM (nazwane od pierwszych liter genów odkrytych u drożdży - ZIP1-4, MSH4/5 i MER3). Dodatkowo, rekombinazy niespecyficzne dla mejozy, głównie MUS81, mogą prowadzić do powstawania crossing-over klasy II, które nie są wrażliwe na interferencję - mają przypadkowe rozmieszczenie na chromosomie (Tabela 1) [11]. Produkty pośrednie rekombinacji, które nie uformują struktury $\mathrm{dHJ}$, naprawiane są poprzez noncrossover, głównie w oparciu o szlak łączenia nici zależny od syntezy DNA (ang. synthesis-dependent strand annealing, SDSA).
Tabela 1. Porównanie mejotycznych szlaków rekombinacyjnych.

\begin{tabular}{|c|c|c|}
\hline & $\begin{array}{l}\text { Szlak I } \\
\text { crossing-over }\end{array}$ & $\begin{array}{l}\text { Szlak II } \\
\text { crossing-over }\end{array}$ \\
\hline Alias nazwy szlaku & ZMM & MUS81 \\
\hline Główna endonukleaza & MLH1-MLH3-EXO1 & MUS81-EME1 \\
\hline $\begin{array}{l}\text { Interferencja } \\
\text { crossing-over }\end{array}$ & Występuje & Brak \\
\hline $\begin{array}{l}\text { "Obligatoryjne" } \\
\text { crossing-over }\end{array}$ & Występuje & Brak \\
\hline $\begin{array}{l}\text { Udział w całkowitej } \\
\text { liczbie crossing-over* }\end{array}$ & $85 \%$ & $15 \%$ \\
\hline Naprawa DSB & $\begin{array}{l}\text { Głównie jako } \\
\text { crossing-over }\end{array}$ & $\begin{array}{l}\text { Głównie jako } \\
\text { noncrossover }\end{array}$ \\
\hline $\begin{array}{l}\text { Zjawisko } \\
\text { heterozygotyczności } \\
\text { in cis }\end{array}$ & Uczestniczy & Nie uczestniczy \\
\hline $\begin{array}{l}\text { Szlak specyficzny } \\
\text { dla mejozy }\end{array}$ & Tak & Nie \\
\hline
\end{tabular}

\section{CZYNNIKI WPEYWAJACE NA FORMOWANIE ZDARZEŃ CROSSING-OVER IN CIS}

Struktura chromatyny wzdłuż chromosomu odgrywa ważną rolę $\mathrm{w}$ formowaniu crossing-over. Tzw. gorące miejsca dla DSB (ang. DSB hotspots) powstają przede wszystkim $\mathrm{w}$ regionach chromatynowych wolnych od nukleosomów, 
co wskazuje, że nukleosomy bezpośrednio blokują dostęp do DNA dla SPO11 i białek mu towarzyszących [12]. U wielu ssaków gorące miejsca DSB determinowane są przede wszystkim przez działanie mejozo-specyficznej metyltransferazy histonowej PRDM9. Co więcej, struktura chromatyny kształtuje wzory rekombinacji wzdłuż chromosomu - crossing-over nie zachodzi np. w regionach centromerowych, co ważne jest dla integralności genomu, jako że zdarzenia crossing-over występujące $\mathrm{w}$ centromerach łączone są z zaburzeniami w rozchodzeniu się chromosomów i aneuploidią. W sąsiedztwie centromerów występuje duże zagęszczenie sekwencji powtarzających się, transpozonów jak i powtórzeń satelitarnych, które współtworzą niedostępną dla maszynerii rekombinacyjnej heterochromatynę. Regiony te charakteryzują się dimetylacją histonu $\mathrm{H} 3 \mathrm{w}$ miejscu lizyny 9 (H3K9me2) oraz metylacją DNA w kontekstach sekwencji CG, CHG i CHH. U Arabidopsis inaktywacja genów odpowiedzialnych za owe modyfikacje chromatyny zwiększa częstość rekombinacji mejotycznej w sąsiedztwie centromerów, na co wpływ mają prawdopodobnie oba szlaki powstawania crossing-over (klasa I i II). Ponadto, w mutancie metyltransferazy DNA met1, nie tylko usunięta jest metylacja DNA w kontekście CG z regionów przycentromerowych, ale również dochodzi do zwiększenia poziomu DSB, co wynika z redukcji ilości nukleosomów okupujących centromer [13].

Obecność polimorfizmów pomiędzy chromosomami homologicznymi (stan heterozygotyczności) również wpływa na dystrybucję crossing-over. Zjawisko redystrybucji crossing-over w odpowiedzi na wzór heterozygotyczności in cis (ang. heterozygosity juxtaposition effect) występuje wtedy, gdy obok siebie na chromosomie sąsiadują regiony heterozygotyczne i homozygotyczne; w takiej sytuacji region polimorficzny otrzymuje więcej zdarzeń crossing-over należących do klasy I [14]. Jednocześnie częstość crossing-over w regionach homozygotycznych ulega zmniejszeniu, więc ogólna ilość crossing-over powstających na chromosomie nie ulega zmianie. W przypadku braku w komórce crossing-over klasy I efekt heterozygotyczności in cis nie występuje, co zbadano poprzez inaktywację ZIP4, jednego z białek ZMM (szlak I), przy jednoczesnym wyłączeniu anty-rekombinacyjnej helikazy FANCM, blokującej klasę II. Zastosowanie podwójnego mutanta jest konieczne, jako że mutanty genów ZMM, w związku z brakiem obligatoryjnego crossing-over, są praktycznie sterylne, co uniemożliwiałoby przeprowadzenie eksperymentów, zaś wyłączenie jednego z anty-rekombinacyjnych czynników przywraca płodność. Aktywność jedynie klasy II spowodowała dwukrotny wzrost częstości rekombinacji, jednak wyłącznie w regionach niezawierających polimorfizmy. Wydaje się więc, że szlak II nie jest w stanie procesować produktów pośrednich rekombinacji w regionach heterozygotycznych, co również wskazuje na zależność częstości crossing-over od gęstości polimorfizmów.

Za zjawisko heterozygotyczności in cis odpowiada białko MSH2, kluczowy element systemu MMR (system naprawy nieprawidłowo sparowanych zasad DNA, ang. DNA mismatch repair system), które jest głównym detektorem niedopasowań DNA w komórce [15]. Białko MSH2 rozpoznaje polimorfizmy i prawdopodobnie nakierowuje na nie kompleks MutL, w skład którego wchodzi białko MLH1, uczestniczące również w formowaniu crossing-over szlaku I. W konsekwencji polimorficzne regiony na chromosomie otrzymują więcej zdarzeń crossing-over.

\section{CZYNNIKI WPEYWAJACE NA FORMOWANIE ZDARZEŃ CROSSING-OVER IN TRANS}

Trans-modyfikatory zdarzeń crossing-over to czynniki, które wpływają na rekombinację bez względu na ich lokalizację na chromosomie. Jednym z takich białek jest konserwatywna ligaza ubikwityny/SUMO - HEI10, która jest niezbędna w szlaku ZMM. Działanie HEI10 jest wysoce zależne od poziomu jej ekspresji - zwiększenie ekspresji HEI10 poprzez dodanie dodatkowych kopii genu nawet dwukrotnie zwiększa częstość zdarzeń crossing-over wzdłuż euchromatyny [16]. Innym czynnikiem, zidentyfikowanym $\mathrm{u}$ Arabidopsis, jest TAF4b (TBP-ASSOCIATED FACTOR 4b), który koduje podjednostkę czynnika transkrypcyjnego TFIID polimerazy RNA II. W mutancie taf4b dochodzi do obniżenia liczby crossing-over, głównie w regionach subtelomerowych [17].

U Arabidopsis jak dotąd opisano trzy główne szlaki anty-rekombinacyjne, na których działanie wpływają białka: FANCM (Fanconi anemia complementation group M) [18], RECQ4 [19] oraz FIGL1 (AAA-ATPase FIDGETIN-LIKE-1) [20]. FIGL1 oddziałuje z rekombinazami RAD51 i DMC1, blokując je i tym samym wpływając na etap inwazji homologicznej nici DNA, ograniczając ilość zdarzeń crossing-over klasy II. FANCM i RECQ4 to helikazy, które również wpływają na formowanie crossing-over klasy II, zależnej od MUS81 (Ryc. 1). Ich działanie polega jednak na rozplataniu cząsteczek DNA - produktów pośrednich rekombinacji i odrzucaniu inwazyjnej nici DNA, co uniemożliwia powstanie crossing-over. Odrzucona nić może połączyć się z wolnym 3' końcem podwójnego pęknięcia DNA, przechodząc proces SDSA. Interesujące jest, iż helikazy FANCM i RECQ4 w różnym stopniu reagują na obecność polimorfizmów pomiędzy rekombinującymi homologami. W mutancie fancm częstość rekombinacji wzrasta $\sim 3$-krotnie jedynie w przypadku braku polimorfizmów, czyli gdy chromosomy homologiczne są identyczne. Natomiast w recq4 wzrost częstości crossing-over zależy od poziomu heterozygotyczności [21] - w hybrydach zaobserwowano wzrost $\sim 4$-krotny, natomiast aż 6-krotny w krzyżówkach wsobnych. Wyraźnie wskazuje to więc, że oba szlaki antyrekombinacyjne są wrażliwe na obecność polimorfizmów pomiędzy rekombinującym DNA, co wpływa na decyzję o naprawie poprzez crossing-over lub noncrossover.

\section{SYSTEM NAPRAWY NIEPRAWIDŁOWO SPAROWANYCH ZASAD DNA}

System MMR zapewnia integralność genomu poprzez rozpoznawanie i naprawę niedopasowań pomiędzy obydwiema nićmi DNA. Niedopasowania te wynikają z błędów polimerazy podczas replikacji DNA oraz powstają $\mathrm{w}$ wyniku uszkodzeń oksydacyjnych, działania niektórych związków chemicznych czy promieniowania UV-B. Mutacje w genach systemu MMR wpływają na zwiększoną predyspozycję do rozwoju niektórych rodzajów nowotworów, 


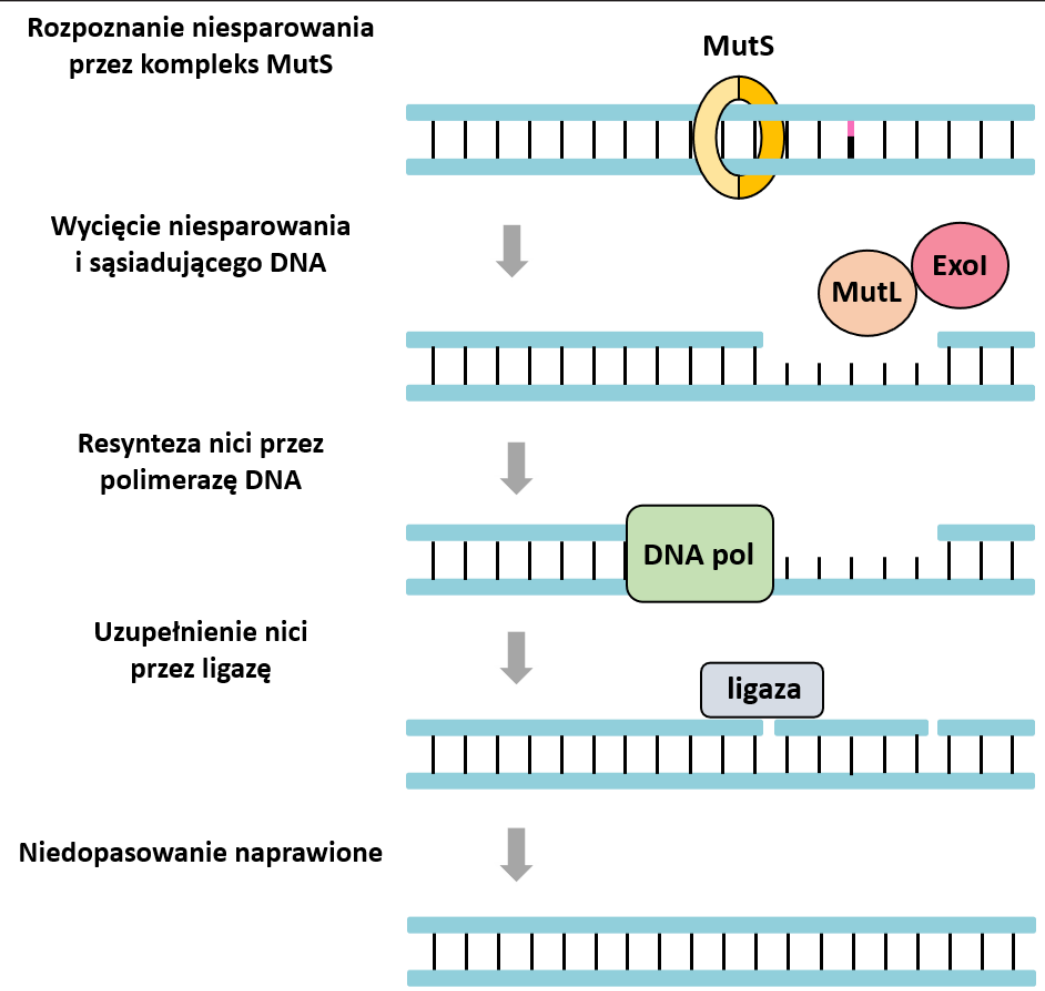

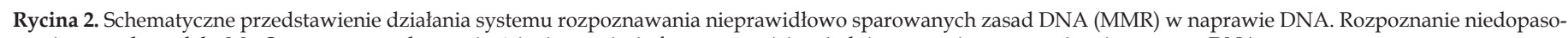
wania przez kompleks MutS tworzący strukturę pierścienia, wycięcie fragmentu nici sąsiadującego z niesparowaniem i resynteza DNA.

wykształcenie oporności na chemoterapeutyki, na wystąpienie nieprawidłowości podczas podziału mejotycznego i niepłodność u ssaków [22]. U roślin także obserwuje się akumulację mutacji w kolejnych pokoleniach, gdy wyłączony jest gen $M S H 2$, co może znacząco wpływać na fenotyp, np. na płodność rośliny [23].

Mechanizm działania systemu MMR został szczegółowo zbadany w komórkach somatycznych. Polega on na rozpoznaniu nieprawidłowo sparowanych miejsc, wycięciu DNA otaczającego niedopasowanie oraz resyntezie nici przez polimerazę naprawczą (Ryc. 2). Niedopasowania rozpoznawane są przez heterodimer MutS, w skład którego zawsze wchodzi białko MSH2, a ponadto MSH3, MSH6 lub MSH7 (specyficzne dla roślin). Wyłączenie genu kodującego białko MSH2 inaktywuje cały system MMR, jako że białko to wchodzi w skład wszystkich kompleksów MutS. Kompleksy MutS tworzą strukturę pierścienia, który skanuje DNA w poszukiwaniu błędów - niedopasowania pojedynczych zasad lub większych insercji i delecji. Po rozpoznaniu niedopasowania, MutS rekrutuje kompleks MutL (MLH1-PMS1), który wykazuje aktywność endonukleazy. DNA sąsiadujące $\mathrm{z}$ niedopasowaniem jest wycinane przez egzonukleaze EXO1, a jednoniciowe DNA stabilizowane przez białko RPA. Po usunięciu niesparowania, nić DNA jest resyntezowana przez polimerazę oraz łączona przez ligazę DNA, co finalizuje proces naprawczy $[24,25]$.

\section{WPEYW SYSTEMU MMR NA REKOMBINACJĘ MEJOTYCZNĄ}

Udowodniono, że białka kompleksów MutS, niezbędne składowe systemu MMR, mogą mieć anty-rekombinacyj- ną rolę, gdyż posiadają zdolność rozpoznawania niedopasowań oraz jednocześnie oddziaływania z produktami pośrednimi rekombinacji - np. poprzez rozplatanie heterodupleksu DNA lub aktywację tego procesu przy udziale helikaz [26].

U Arabidopsis thaliana, MSH2 zostało opisane jako czynnik anty-rekombinacyjny, działający poprzez supresję rekombinacji pomiędzy chromosomami homologicznymi pochodzącymi z różnych ekotypów (pomiędzy którymi występują polimorfizmy DNA; [27]). Natomiast w analizach całogenomowych pokazano, że wyłączenie MSH2 skutkuje redystrybucją zdarzeń crossing-over z wysoce polimorficznych regionów pericentromerowych do mniej polimorficznych subtelomerowych, nie zaobserwowano jednak zmiany w ogólnej liczbie crossing-over [15].

U roślin MSH2 może mieć podwójną rolę, zależną od kontekstu genomowego, gdyż w pewnych warunkach pełni też funkcję pro-rekombinacyjną. Jak już wspomniano, białko MSH2 jest odpowiedzialne za redystrybucje crossing-over w odpowiedzi na wzór heterozygotyczności in cis rozpoznaje polimorfizmy i stymuluje crossing-over w regionach polimorficznych, prawdopodobnie poprzez rekrutacje mejozo-specyficznego kompleksu MLH1-MLH3 (zwanego MutLү), działającego $\mathrm{w}$ formowaniu zdarzeń crossing-over klasy I [15]. Akumulacja kompleksu MutLy na dHJ powoduje przekształcenie rekombinujących nici $\mathrm{w}$ zdarzenie crossing-over klasy I. MutLy posiada aktywność endonukleazy i uważane jest za rezolwazę $\mathrm{dHJ}$, potrzebną do naprawy tej struktury na drodze crossing-over - w przypadku braku MutLy, dHJ przekształcana jest do noncrossover [28]. 
Występowanie zjawiska heterozygotyczności in cis ma kolosalne znaczenie $\mathrm{w}$ utrzymywaniu zmienności populacyjnej genomów roślinnych, które wykazują się wysokim poziomem wsobności w wyniku samopylności - gdyby crossing-over zachodziło wyłącznie w regionach homozygotycznych, przetasowanie materiału genetycznego $\mathrm{w}$ mejozie byłoby znacząco ograniczone. To skutkowałoby ograniczeniem zmienności genotypów w kolejnych pokoleniach, a w konsekwencji ewolucja organizmów byłaby ograniczona.

Częściowo przeciwstawne wyniki dla MSH2 opisano $\mathrm{u}$ drożdży. Mutanty msh2 wykazywały ogólny wzrost liczby crossing-over i ich redystrybucję do regionów polimorficznych [29] wskazując na antyrekombinacyjne działanie MSH2. Jednocześnie badania in vitro pokazały, że heterodimer MSH2-MSH3 stymuluje kompleks MutLy (MLH1-MLH3), który jest niezbędny do formowania crossing-over klasy I [30].

Dodatkowe funkcje kompleksu MMR w mejozie zostały opisane $u$ pszenicy. Pszenica zwyczajna (Triticum aestivum) jest heksaplodiem, posiada więc 6 zestawów chromosomów (AABBDD), które pochodzą z międzygatunkowego krzyżowania się trzech diploidów. Te zestawy chromosomów są względem siebie homeologiczne, a więc nie ma między nimi pełnej homologii. Aby zapewnić stabilność genomu, w trakcie mejozy nie może dochodzić do crossing-over pomiędzy chromosomami homeologicznymi - dopuszczalna jest jedynie rekombinacja pomiędzy homologami w obrębie tego samego genomu pszenicznego. Rekombinacja homeologiczna jest blokowana przez dwa chromosomowe loci: Ph1 i Ph2 (Pairing homoelogous 1 i 2). Genem odpowiedzialnym za Ph1 jest ZIP4, jedno z białek ZMM [31, 32], natomiast jako główny czynnik odpowiedzialny za locus Ph2 zidentyfikowano niedawno gen MSH7 [33]. Wskazuje to na rolę MSH7, białka systemu MMR, w stabilizacji poliploidów podczas podziału mejotycznego u roślin.

\section{MutS W KONTROLI FORMOWANIA ZDARZEŃ CROSSING-OVER KLASY I I II}

Redystrybucja zdarzeń crossing-over do polimorficznych rejonów chromosomowych, czyli zjawisko heterozygotyczności in cis, zależna jest od występowania interferujących crossing-over szlaku I. W przypadku wyłączenia szlaku I w komórce, efekt heterozygotyczności in cis nie występuje, zaś szlak II wrażliwy jest na obecność polimorfizmów i powoduje powstanie crossing-over jedynie w regionach homozygotycznych. Zjawisko heterozygotyczności in cis kontrolowane jest przez białko MSH2, co sugeruje jego interakcję z maszynerią klasy I.

Badania drożdżowe pokazały, że białka MSH2 i MSH6 oddziałują z helikazą SGS1 (drożdżowy homolog RECQ4), anty-rekombinacyjnym czynnikiem działającym w II szla$\mathrm{ku}$ crossing-over, powodującym odrzucenie heterodupleksu podczas procesu dopasowania pojedynczych nici DNA (ang. single-strand annealing, SSA), jednego z mechanizmów naprawy DSB w komórkach somatycznych [34]. U ludzi zaobserwowano, iż kompleks MSH2-MSH6 może stymulo- wać rozplatanie heterodupleksowego DNA przez oddziaływanie $\mathrm{z}$ helikazą WRN, należącą do tej samej rodziny co RECQ4 i SGS1 [35].

Obecność polimorfizmów pomiędzy rekombinującymi chromosomami różnych gatunków może doprowadzać do tzw. sterylności mieszańców, czyli niemożności zajścia crossing-over, a w konsekwencji zaburzeń w rozchodzeniu się chromosomów i aneuploidii. U Saccharomyces cerevisiae i S. paradoxus, których genomy różnią się w ok. 12\%, hybrydy są sterylne. Poprzez wyłączenie dwóch genów, MSH2 i SGS1, udało się zwiększyć płodność hybryd aż o 70\% [36].

Te oraz podobne obserwacje wskazują, że kompleks MutS wpływa na zachodzenie crossing-over zarówno w klasie I, jak i w klasie II, przy czym przypuszczalnie efekty dla tych dwóch szlaków są przeciwstawne. Dlaczego tak się dzieje? Trzeba pamiętać, że szlak ZMM tworzący crossing-over klasy I jest głównym szlakiem zapewniającym rekombinację $\mathrm{w}$ mejozie, dominującym u większości eukariotów. Rekombinacja mejotyczna ma za zadanie przetasowanie chromosomów pochodzących od obojga rodziców, zatem jest niejako predysponowana do zachodzenia pomiędzy chromosomami różniącymi się $\mathrm{w}$ pewnym stopniu sekwencją. Zatem zablokowanie przez MutS crossing-over klasy I pomiędzy polimorficznymi względem siebie chromosomami homologicznymi mogłoby prowadzić do braku rekombinacji i w konsekwencji nieprawidłowej segregacji chromosomów. Z kolei klasa II crossing-over jest szlakiem dodatkowym, którego główna rola polega na naprawie przypadkowych dwuniciowych pęknięć DNA w komórkach somatycznych. Nie zależy ona od prawidłowego parowania chromosomów, w związku z czym mogłaby prowadzić do przypadkowej rekombinacji między losowymi fragmentami DNA - stąd pojawia się potrzeba jej blokowania przez system MutS w przypadku wykrycia niedopasowań. Dalsze badania będą prawdopodobnie skupiały się na określeniu, w jakim stopniu system MMR, rozpoznający polimorfizmy, kontroluje także powstawanie crossing-over szlaku I oraz II, a także czy białka MMR oddziałują z innymi elementami maszyny rekombinacyjnej.

\section{PIŚMIENNICTWO}

1. Bolcun-Filas E, Handel MA (2018) Meiosis: the chromosomal foundation of reproduction. Biol Reprod 1: 112-126.

2. Mercier R, Mézard C, Jenczewski E, Macaisne N, Grelon M (2015) The Molecular Biology of Meiosis in Plants. Annu Rev Plant Biol 1: 297-327.

3. He Y, Wang M, Dukowic-Schulze S, Zhou A, Tiang C-L, et al. (2017) Genomic features shaping the landscape of meiotic double-strandbreak hotspots in maize. Proc Natl Acad Sci U S A 46: 12231-12236.

4. Choi K, Zhao X, Kelly KA, Venn O, Higgins JD, et al. (2013) Arabidopsis meiotic crossover hot spots overlap with H2A.Z nucleosomes at gene promoters. Nat Genet 11: 1327-1336.

5. Martini E, Diaz RL, Hunter N, Keeney S (2006) Crossover homeostasis in yeast meiosis. Cell 2: 285-295.

6. Dluzewska J, Szymanska M, Ziolkowski PA (2018) Where to Cross Over? Defining Crossover Sites in Plants. Front Genet: 609.

7. Neale MJ, Keeney S (2006) Clarifying the mechanics of DNA strand exchange in meiotic recombination. Nature 7099: 153-158.

8. Hunter N (2015) Meiotic Recombination: The Essence of Heredity. Cold Spring Harb Perspect Biol 7: a016618.

9. Sturtevant AH (1913) A Third group of linked genes in Drosophila ampelophila. Science 965: 990-992. 
10. Zickler D, Kleckner N (2016) A few of our favorite things: Pairing, the bouquet, crossover interference and evolution of meiosis. Semin Cell Dev Biol 54: 135-148.

11. Berchowitz LE, Francis KE, Bey AL, Copenhaver GP (2007) The Role of AtMUS81 in Interference-Insensitive Crossovers in A. thatiana. PLOS Genet 8: e132.

12. Choi K, Zhao X, Tock AJ, Lambing C, Underwood CJ, et al. (2018) Nucleosomes and DNA methylation shape meiotic DSB frequency in Arabidopsis thaliana transposons and gene regulatory regions. Genome Res 4: 532-546.

13. Underwood CJ, Choi K, Lambing C, Zhao X, Serra H, et al. (2018) Epigenetic activation of meiotic recombination near Arabidopsis thaliana centromeres via loss of $\mathrm{H} 3 \mathrm{~K} 9 \mathrm{me} 2$ and non-CG DNA methylation. Genome Res 4: 519-531.

14. Ziolkowski PA, Berchowitz LE, Lambing C, Yelina NE, Zhao X, et al. (2015) Juxtaposition of heterozygous and homozygous regions causes reciprocal crossover remodelling via interference during Arabidopsis meiosis. Elife: 4: e03708.

15. Blackwell AR, Dluzewska J, Szymanska-Lejman M, Desjardins S, Tock AJ, et al. (2020) MSH 2 shapes the meiotic crossover landscape in relation to interhomolog polymorphism in Arabidopsis. EMBO J 39: e104858.

16. Ziolkowski PA, Underwood CJ, Lambing C, Martinez-Garcia M, Lawrence EJ, et al. (2017) Natural variation and dosage of the HEI10 meiotic E3 ligase control Arabidopsis crossover recombination. Genes Dev 3: 306-317.

17. Lawrence EJ, Gao H, Tock AJ, Lambing C, Blackwell AR, et al. (2019) Natural Variation in TBP-associated Factor $4 \mathrm{~b}$ Controls Meiotic Crossover and Germline Transcription in Arabidopsis. Curr Biol 16: 26762686.e3.

18. Crismani W, Girard C, Froger N, Pradillo M, Santos JL, et al. (2012) FANCM Limits Meiotic Crossovers. Science 336: 1588-90.

19. Séguéla-Arnaud M, Crismani W, Larchevêque C, Mazel J, Froger N, et al. (2015) Multiple mechanisms limit meiotic crossovers: TOP3a and two BLM homologs antagonize crossovers in parallel to FANCM. Proc Natl Acad Sci 15: 4713-4718.

20. Girard C, Chelysheva L, Choinard S, Froger N, Macaisne N, et al. (2015) AAA-ATPase FIDGETIN-LIKE 1 and Helicase FANCM Antagonize Meiotic Crossovers by Distinct Mechanisms. PLOS Genet 7: e1005369.

21. Fernandes JB, Séguéla-Arnaud M, Larchevêque C, Lloyd AH, Mercier R (2018) Unleashing meiotic crossovers in hybrid plants. Proc Natl Acad Sci US A 10: 2431-2436.

22. Li G-M (2008) Mechanisms and functions of DNA mismatch repair. Cell Res 1: 85-98.
23. Hoffman PD, Leonard JM, Lindberg GE, Bollmann SR, Hays JB (2004) Rapid accumulation of mutations during seed-to-seed propagation of mismatch-repair-defective Arabidopsis. Genes Dev 21: 2676-2685.

24. Jiricny J (2006) The multifaceted mismatch-repair system. Nat Rev Mol Cell Biol 5: 335-346.

25. Manhart CM, Alani E (2016) Roles for mismatch repair family proteins in promoting meiotic crossing over. DNA Repair (Amst) 38: 84-93.

26. Chakraborty U, Alani E (2016) Understanding how mismatch repair proteins participate in the repair/anti-recombination decision. FEMS Yeast Res 6: fow071.

27. Emmanuel E, Yehuda E, Melamed-Bessudo C, Avivi-Ragolsky N, Levy AA (2006) The role of AtMSH2 in homologous recombination in Arabidopsis thaliana. EMBO Rep 7: 100-5.

28. Kulkarni DS, Owens SN, Honda M, Ito M, Yang Y, et al. (2020) PCNA activates the MutLy endonuclease to promote meiotic crossing over. Nature 586: 623-627.

29. Cooper T, Crawford M, Hunt L, Marsolier-Kergoat M-C, Llorente B, et al. (2018) Mismatch Repair Impedes Meiotic Crossover Interference. bioRxiv 480418.

30. Rogacheva M V, Manhart CM, Chen C, Guarne A, Surtees J, et al. (2014) Mlh1-Mlh3, a meiotic crossover and DNA mismatch repair factor, is a Msh2-Msh3-stimulated endonuclease. J Biol Chem 9: 56645673.

31. Griffiths S, Sharp R, Foote TN, Bertin I, Wanous M, et al. (2006) Molecular characterization of $\mathrm{Ph} 1$ as a major chromosome pairing locus in polyploid wheat. Nature 439: 749-752.

32. Rey M-D, Martín AC, Smedley M, Hayta S, Harwood W, et al. (2018) Magnesium Increases Homoeologous Crossover Frequency During Meiosis in ZIP4 (Ph1 Gene) Mutant Wheat-Wild Relative Hybrids. Front Plant Sci: 9: 509.

33. Serra H, Svačina R, Baumann U, Whitford R, Sutton T, et al. (2021) Ph2 encodes the mismatch repair protein MSH7-3D that inhibits wheat homoeologous recombination. Nat Commun 120: 803.

34. Onoda F, Seki M, Wang W, Enomoto T (2004) The hyper unequal sister chromatid recombination in an sgs1 mutant of budding yeast requires MSH2. DNA Repair (Amst) 10: 1355-1362.

35. Saydam N, Kanagaraj R, Dietschy T, Garcia PL, Peña-Diaz J, et al (2007) Physical and functional interactions between Werner syndrome helicase and mismatch-repair initiation factors. Nucleic Acids Res 17: 5706-5716.

36. Bozdag GO, Ono J, Denton JA, Karakoc E, Hunter N, et al. (2021) Breaking a Species Barrier by Enabling Hybrid Recombination. Curr Biol 4: R180-R181. 


\section{The role of MutS complex and MSH2 protein in the crossover control in plants}

\section{Julia Dłużewska ${ }^{\varpi}$, Piotr A. Ziółkowski ${ }^{\varpi}$}

Laboratory of Genome Biology, Institute of Molecular Biology and Biotechnology, Faculty of Biology, Adam Mickiewicz University in Poznan

${ }^{\natural}$ Corresponding authors: dluzewska1@gmail.com (J.D.), pzio@amu.edu.pl (P.Z.)

Key words: meiosis, crossover, Arabidopsis, MSH2, polymorphisms

\section{ABSTRACT}

Crossover is a reciprocal exchange of chromatid fragments between homologous chromosomes and takes place during second meiotic division. Many factors affect the distribution and frequency of crossovers - for instance, the activity of trans-acting modifiers, chromatin methylation level or the presence of polymorphisms between recombining chromosomes. MMR system, and specifically MSH2 protein, serves to recognize and repair mismatched DNA bases, and prevents recombination between divergent chromosomal regions during meiosis. Unexpectedly, MSH2 displays also a pro-recombination role in plants by detecting polymorphisms and directing crossover events into more diverged regions. In this review, we demonstrate how interhomolog polymorphism may affect crossover chromosomal distribution and, as a consequence, plant genomes evolution. It is especially important for self-fertilizing plants which naturally exhibit high level of homozygosity. If recombination were to occur only in homozygous regions, no new genotypes would be created in subsequent generations, slowing down the evolution of the organisms.

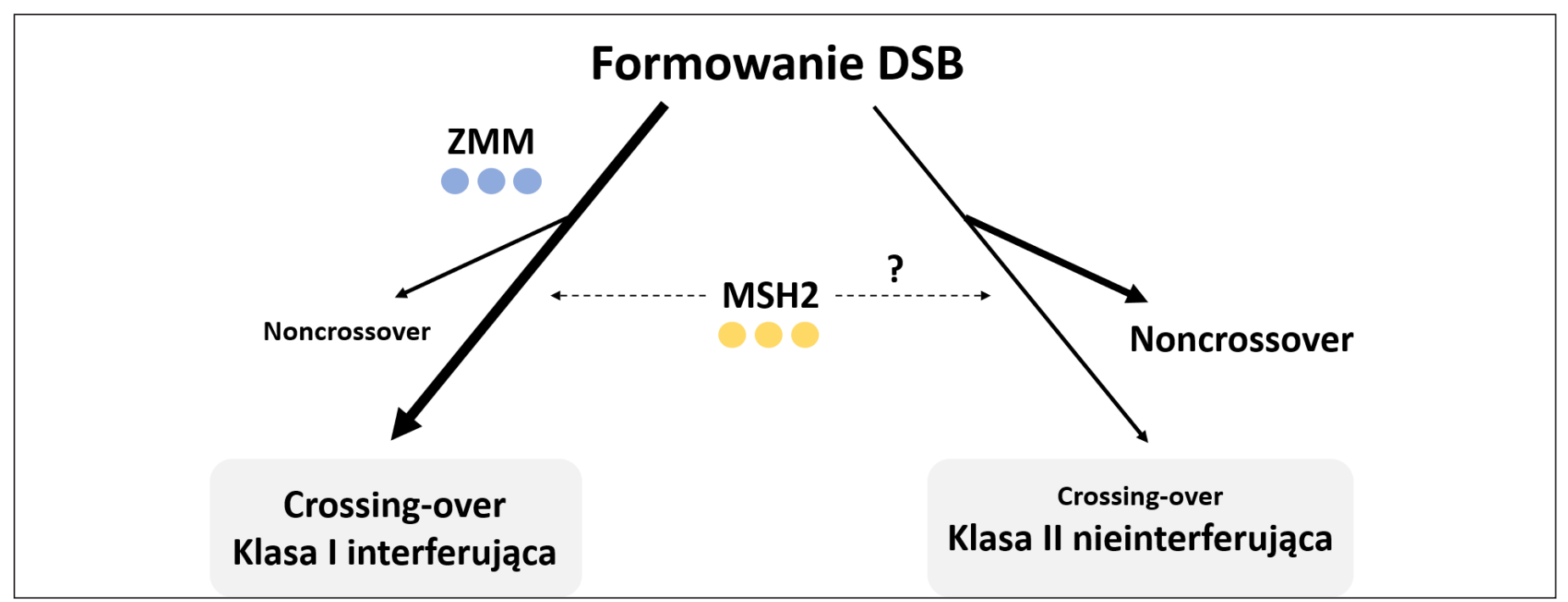

